\title{
Communication, Differentiation and the Evolution of World Society ${ }^{*}$
}

\author{
Boris Holzer
}

\begin{abstract}
The history of globalization is intertwined with the history of communication technologies. From a sociological perspective, innovations and developments of both mass media and symbolically generalized media shape the structure of social contacts. Concerning the nexus between globalization and communication, I distinguish three analytically distinct yet partially overlapping phases of globalization: In a first phase, communication became universal by incorporating the globe into networks of exchange, power and belief. In a second phase, communication became instantaneous by means of telecommunication. In a third phase, increasing differentiation within subsystems of society created incentives to communicate across the globe. In their combination, these processes have resulted in the fusion of horizons of meaningful action into a singular global frame of reference. However, that does not imply uniformity since that global frame of frame has also institutionalized a preference for continuous change and variation.
\end{abstract}

\section{Introduction}

We tend to think that the history of world society begins in the $19^{\text {th }}$ century, but in fact, a pattern of 'archaic globalization' based on the exchange of commodities and on intercultural contacts had already emerged long before (Bayly, 2004, 2005). Interconnectedness as we usually think of it, however, scarcely existed up until the mid- $19^{\text {th }}$ century: the many white spots on the maps and the fragmentary character of knowledge of the world inspired Hobsbawm (2004, p. 59) to state that 'there was not, even in terms of geographical knowledge, one world.' The parameters of global connectedness changed dramatically during the $19^{\text {th }}$ century, however, as railroad tracks and steamship routes allowed traveling within Europe and across the Oceans with unprecedented speed and reliability, and the standardization of time made it possible to know not only where but also when a journey would end. Still, the development of a 'world society' was incremental and not without its hurdles: There were no airplanes and long-distance journeys thus were time-consuming. Large parts of Africa, Asia and even America were still uncharted territories and difficult to reach at all. Telegraph cables connected the major European cities, the Americas and the colonial hubs in Asia, but the steep tariffs for sending messages limited the practical use of the telegraph to political and economic elites and

\footnotetext{
* Preprint, to appear in: What in the World? Understanding Global Social Change, ed. by Mathias Albert and Tobias Werron, Bristol: Bristol University Press 2021
} 
prevented it from becoming a mass medium. The nation-state and national collectives defined the new 'international' political stage, and diplomatic contacts and state visits flourished, yet large parts of the world were either under colonial rule or were governed by non-democratic regimes (if governed at all).

Despite those limitations, some features of contemporary world society were established or had at least begun to emerge by the end of the $19^{\text {th }}$ century, most notably the interconnectedness through transport and communication networks, as well as the standardization and diffusion of political and other social institutions (Osterhammel, 2014). The global infrastructure for transport and communication improved by leaps and bounds: As early as 1872 it was possible to travel around the world in 80 days like Jules Verne's tourist pioneer Phileas Fogg, whereas in 1848, it would have taken a good eleven months. The rapid expansion of the transport infrastructure continued: 10,000 miles of railway lines in 1845 had already grown to 600,000 by 1920 (Lechner \& Boli, 2005, 114f.).

The question of how significant those developments were echoes central topics of the debate about the origins of modernity: Did it start around that time, being basically a correlate of industrialization? Or had earlier political events, notably the French Revolution, already laid the groundwork? And were those actually the final outcomes of a societal transformation that had already begun with the European expansion and the revolution of its worldview in the $15^{\text {th }}$ and $16^{\text {th }}$ centuries?

From a sociological perspective, it is probably neither possible nor necessary to decide these questions. ${ }^{1}$ The question of periodization is not as relevant as the question of how and why some basic structures of contemporary world society emerged at all. In that regard, the 'long' $20^{\text {th }}$ century - from the mid- to late $19^{\text {th }}$ century onwards - is of particular interest. Over a relatively short period of time, multiple transformations of the social world occurred that made global interconnectedness palpable and thereby popularized the aspiration for a global modernity. Even if we cannot observe a fundamental or sudden societal revolution during that period, the long-time transformation of which it forms an integral part is substantial enough to warrant closer inspection.

\footnotetext{
1 Regarding the problem of periodization in global history see Epple (this volume).
} 
Contextualizing the long $20^{\text {th }}$ century requires a conceptual framework. To go beyond collecting and presenting evidence based on more or less spontaneous comparisons between 'now' and 'then', we need to consult a theory of society - not because it could give us an authoritative answer but because it allows us to formulate questions that point to pertinent events and developments. The choice of a systems perspective is usually controversial but in this case more than justified by the fact that communication is of primary interest in this period. Furthermore, the advantage of world society theory compared to, for instance, world-systems or field theories ${ }^{2}$ lies in the fact that it actually combines three distinct yet mutually complementary sets of theories: communication theory, differentiation theory and evolutionary theory. Its take on globalization therefore goes beyond identifying the modes of global transaction or tracing the dynamics of a particular sphere of action. It combines interests in the modes and possibilities of communicative relationships, in the specialization and differentiation of social action, and in the temporal unfolding and change of social structures.

This kind of theoretical design enables us to examine how the globalization of the $19^{\text {th }}$ and $20^{\text {th }}$ century affected social contacts, societal groups and the form of social change itself. Regarding those three aspects, there is some continuity with previous and later forms of (proto-)globalization and there also is an instructive absence of certain features of contemporary globalization. The following sections are therefore structured along these three theoretical perspectives and seek to identify those events and developments that made a difference regarding both previous and later manifestations of globalization.

\section{From universal to instantaneous communication}

Modern globalization cannot be understood merely in terms of material linkages and the mobilities of goods and people, insofar as communication technologies also played a pivotal role in the emergence and integration of world society. The emergence of new technologies of (tele-)communication rendered informational networks independent of physical transportation and thus added a decisive new dimension to globalization (Lübbe, 1996; Wenzlhuemer, 2010). In the 1870 s telegraphic cables already connected Europe, South America, South Africa, Australia, India and China and thus gave rise to a rudimentary form of global connectedness

\footnotetext{
2 See Go (this volume) for an elaboration and application of global field theory.
} 
(Wobring, 2005). New communication technologies played a pivotal role in globalizing economic, political and cultural relations (Osterhammel, 2009, pp. 63-83). It is therefore hardly surprising that the roles of the telegraph, of news agencies and of print media have attracted a good deal of scholarly attention (Müller, 2016; Rantanen, 2009; Tworek, 2014, this volume; Winseck \& Pike, 2007).

But how can we account for the impact that new communication technologies had on social change and on society as a whole? If we understand the long $20^{\text {th }}$ century primarily in terms of the emergence of new forms of mediated communication, a theory of society that focuses on communication should be able to offer some guidance. Yet telegraphy, being the major pertinent innovation of that period, does not fall squarely into either category of Luhmann's (1975b, 1997) theory of communication, which distinguishes between distributive media (e.g. writing, printing, mass media) and 'symbolically generalized media' (money, power, truth, love). Although telegraphy allowed connections to be made across large distances almost instantaneously, it was in fact a point-to-point medium whose tariffs precluded the participation of larger parts of the population: 'The tentacles of global communications in the nineteenth and early twentieth centuries, the dense network of submarine and terrestrial telegraphs, were never a means of social or mass communication' (Müller, 2015, p. 441). However, telegraphy quickly became the backbone for the global operations of international news agencies that were thereby able to deliver news to audiences across the globe at unprecedented speed. The 'dematerialization' (Wenzlhuemer, 2010, 2013) of communication, although more or less limited to political and economic elites, thereby affected a broader audience, too.

The 'network compression' (Lübbe, 1996) effected by telegraphy was able to build on a previous step in the history of global communication: the universalization of communication. Throughout human history, the boundaries of societies had also been 'boundaries of the social world' (Luckmann, 1970). The boundaries drawn by communities of language and descent delimited potential partners for communication; people outside this perimeter were considered 'barbarians' and thus deemed unable to communicate. But even if other (potential) human beings beyond the boundaries of a particular society had to be acknowledged, that did not necessarily imply any interest in establishing social relationships with them. They could be and regularly were regarded as either too remote or too strange to warrant their inclusion within a shared horizon of the social world (Luhmann, 2017, 367f.). Against this backdrop, the European expansion of the $15^{\text {th }}$ and $16^{\text {th }}$ centuries, especially the discovery of the New World, marked a 
significant rupture by establishing a new, inclusive - and for the societies affected often overwhelming or even disastrous - pattern of social contact. The contact with and the integration of other societies was not avoided anymore but became a consciously pursued project. The question of the moral standing of other cultures was still a matter of dispute, as documented by the Valladolid debate (1550-1551) about the rights of the colonized people in the New World (Hanke, 1974). Yet their communicative standing was firmly established - and exploited - by the conquerors, who used the knowledge about the indigenous worldviews in order to manipulate them to their own advantage (Todorov, 1985). Communication, pace Habermas, is not just a medium of understanding but also one of manipulation.

It is therefore no contradiction to note both that communication had become universalized and that it was not motivated by humanistic interest in other cultures but by the promise of economic gain, the pursuit of political expansion and missionary zeal. In order to achieve their goals, conquerors and colonizers had to rely on communication. Ever since the beginning of the European expansion, the history of world society has therefore also meant the expansion of communicative relationships. Those relationships were of course rarely genuine, sociable encounters, but already functionally specific in terms of political, economic, religious, or other criteria. The unity of world society as a system of communication must not be confused with normative integration or even solidarity.

At the beginning of the $19^{\text {th }}$ century, the universalism of communication had already been firmly established but it still had little impact on everyday life. It did not imply that people were in touch across the globe. Besides the often specific and thus socially 'thin' nature of longdistance contacts, it was based on personal encounters and written communication. Newspapers and a 'mobile universe of books' (Osterhammel 2016b: 816ff.) provided an extensive web of communication. But worldwide interpersonal contacts would have been impossible from a technological point of view and meaningless from a socio-cultural one. Yet knowledge about events and people abroad soon became so widely shared that it affected and altered the common-sense view of the world. The possibilities of telegraphic communication, actualized through news agencies since the 1870s, in particular enabled a new 'experience of simultaneity' across the globe (Conrad, 2016, p. 460).

For the majority of the world's population, however, instantaneous communication was at best an imagination rather than an experience. Access to the 'Victorian internet' (Standage, 1998) 
was limited and expensive. Yet the attention attracted by the efforts to install a global network made sure that the possibilities of the new technology became part of the public imagination. The imagery of a global community of communication was further underpinned by a related development, which was stimulated by the demands of transport spanning different time zones: the standardization of time (Zerubavel, 1982). It must be regarded as one of the biggest interventions of society into what had hitherto appeared as a mere fact of nature. The thus established temporal frame of reference for all social action has, of course, become an indispensable backdrop of global connections - physical as well as communicative. But another aspect that deserves attention is the increasing specificity of the 'present.' Within only a couple of decades, a broad and diffuse understanding about what happened where, at roughly what time, gave way to a much narrower understanding of and interest in present events. That 'shrinking of the present' is, for instance, observable in the immediacy of news reports in Germany: While in 1856 only 11 per cent of news was not older than one day, in the year 1906 that rate had risen to 95 per cent (Osterhammel, 2009, 63f.).

The globalization of communication in the $19^{\text {th }}$ century thus greatly enhanced the mutual awareness and perceived simultaneity of events around the world (Werron, 2016). Although that cannot account for the institutionalization of human rights much later, it already served as a backdrop for an emerging normative consensus that everyone should not only be regarded as a potential partner for communication but also as a bearer of rights. Yet it still lacked, probably until well after 1945, a set of global media targeting a global mass audience in all parts of the world (Osterhammel, 2017, p. 34). We can thus discern more clearly how the new technologies of telecommunication laid the foundation for the more far-reaching transformation associated with radio and television. Their effects are in some ways already imminent in the uses of and even more so in the utopias about telegraphy. But those go beyond the societal consequences of telegraphy in at least two ways: First, they took the inclusion of a universal audience to another level by combining more efficient ways of broadcasting with audiovisual information rather than text. Second, they made it plausible to assume that anyone had the same knowledge about current events and thus created a much more immediate sense of a global social reality by way of an 'instantaneous integration' (Sofort-Integration) of world society (Luhmann, 1981, p. 318). In that regard, the telecommunication revolution of the $19^{\text {th }}$ century prepared the ground for future developments that would then fully realize the potential of instantaneous communication. 


\section{Media of communication, universalism and differentiation}

Why did the communication innovations of the 19th century succeed in a way that led to further improvements overcoming their previous shortcomings - especially regarding participation and reliability? Contemporary observers already expressed some doubts about the demand for the new technology, asking why people who are separated not only by spatial but also by cultural distances should be interested in communicating with one another at all (Müller, 2016). Strange as such reservations may seem from today's point of view, there had been little demand for such technologies for thousands of years. If a communication technology offers the potential to transcend limits of space and time, social structures must also give reasons to actually use it. Differentiation, particularly functional differentiation, does precisely that.

As noted above, the expansion of social relationships has long since been associated with functionally specific communication, particularly with economic, political and religious forms of contact, exchange and domination. There are at least two different ways to theorize the link between functional differentiation and globalization: The first one highlights the 'specific universalism' of functionally specified communication, the second one, the increasing heterogeneity of functionally differentiated role structures. These two lines of argument are complementary but they may also be regarded as ways to address both the generic question of globalization and the changes that took place during the $19^{\text {th }}$ century.

Although functional differentiation is closely intertwined with expansion, the shape and extent of globalization depends on the medium of communication. In terms of communication, the globalizing dynamics of functional subsystems rest with what has been dubbed 'specific universalism:' Within the specific demarcations of their functional domain, such subsystems adopt a universalistic perspective, i.e. they observe anything and everything under the auspices of their 'code.' From the perspective of the economy, anything may be monetized, and from the perspective of the political system, anything may be turned into a matter of collective decision-making. Generally speaking, expansion therefore is a correlate of the functional specialization of societal subsystems.

Major subsystems are associated with specific 'symbolically generalized media of communication' such as money, power, truth and love (Luhmann, 1975b). The fact that the 
economy, based on money, and science, based on truth, appear to be more effectively global in their operations has to do with the fact that their media revolve around the problem of transmitting and motivating certain kinds of experience, not of social action: The acceptance of truth or property claims merely requires adjusting one's expectations, whereas power is only effective to the extent that it motivates a particular course of action. Globalization in terms of extensive and intensive communicative relationships across distance therefore occurs most prominently in those fields that do not require a collective coordination of action (Luhmann, 1975a, 55ff., 2017, p. 445).

Consider the case of modern science, whose mode of communication is fundamentally predicated upon the assumption that (scientific) truths are amenable to intersubjective validation and thus universal. Nothing could be farther removed from the scientific enterprise than Pascal's lament: 'Truth on this side of the Pyrenees, error on the other side' (Pascal, 1910, p. 104). In fact, Pascal made this remark in the context of his observations about the vicissitudes of standards of justice and thus referred to 'moral' truth, which obviously cannot lay claim to universal validity to the same extent as scientific truth. Although the universalism of scientific knowledge has been contested throughout history, the argument that truth and, in a similar vein, money foster globalizing perspectives in their respective domains is borne out by the high degree of transnationalization of both science and the economy in contemporary world society.

Politics, in contrast, appears to have followed a different path: From the late $18^{\text {th }}$ century onwards, a global political system has emerged, but it remains based on nation-states. However, the paramount role of the nation-state, i.e. the "primacy of segmentation in the system of world politics" (Albert, 2016, p. 150) should not be misunderstood as an argument against globalization. In fact, the structural isomorphism of nation-states as well as the diffusion of nationalism(s) are consequences of globalization (Meyer, Boli, Thomas, \& Ramirez, 1997; Stichweh, 2002; Werron, 2018, this volume). Yet the peculiar differentiation of the global political system into such units may have to do with peculiarities of power as a medium of communication: Power means to control someone else's actions through the threat of sanctions (Luhmann, 1979). It therefore presupposes a certain social proximity, for instance, to allow one to observe obedience or resistance. Although power may of course be used to establish hierarchies and chains of command, there are limits to the spatial expansion and social inclusiveness of such concatenations. 
The analysis of the impact of symbolically generalized media yields some insights into the globalizing dynamics associated with modern society in general. It also helps us to understand why different social fields are more or less amenable to globalization. It does not, however, provide many clues as to specific historic developments, particularly concerning innovations of 'distributive' media of communication. In order to bring this aspect into relief, we need to consider how the differentiation of social structures impinges on the likelihood of long-distance contacts.

The argument that social differentiation entails the spatial expansion of relationships was originally put forward by Georg Simmel: Differentiation means that formerly homogeneous social groups become more heterogeneous. New distinctions make people who used to be quite similar more and more different, and individualization is thus increased. The differentiation of social structures therefore 'loosens the bond to what is close by, weaving instead a new bond real and ideal - to what is further away' (Simmel, 1958 [1908], p. 530). In order to find a match for one's increasingly idiosyncratic combination of traits, the individual is driven to look for contacts beyond the social environment at hand.

This argument can be generalized beyond its focus on individuals and their group affiliations. Interests that motivate social contacts beyond 'what is close by' are related to subsystems of society that generate their own and very specific criteria of relevance. Science is a case in point, exhibiting both a long history of long-distance contacts and a more recent increase of differentiation through the establishments of new disciplines. Particularly in the late $19^{\text {th }}$ and early $20^{\text {th }}$ century the globalization of science was driven by the increasing differentiation of the scientific field in specialized sub-disciplines, which lend new momentum to the institutionalization of communicative relationships beyond national borders (Stichweh, 2000, 2003). Echoing Simmel's argument, ethnologist Fredrik Barth describes the situation of the scientific specialist as follows: 'A scholar of Ugric languages wishing to discuss his latest paper on the structure of conditional clauses cannot go next door: like the lonely whales of Antarctica searching for a mate, he must seek a suitable partner for his task widely through the seas of society' (Barth, 1978, p. 168). The more specialized scientific interests become, the more likely they require long-distance contacts among scientists. Among the structural consequences of the increasing internal differentiation of the system of science that became more and more salient after 1780 were the emergence of today's scientific disciplines, the coupling of research and 
higher education in universities and the increasingly specialized communication through journals (Stichweh, 2001).

Differentiation thus gives rise to new criteria of difference and similarity that stimulate longdistance communication to establish relationships with other like units. A slightly different manifestation of such a development has taken place in the political realm. The affinity between political regimes and communication technology is well established. Its most salient feature is how communication technology bolstered the internal integration of political units: Writing, in particular, offered entirely new opportunities for political integration and accordingly was a prerequisite for large empires (Innis, 1972). Later on, innovations such as telegraphy were employed as effective instruments of imperial control across distances (Wenzlhuemer, 2013, Ch. 4; Winseck \& Pike, 2007). Telecommunication served to enhance the administrative power of colonial regimes but also gave their opponents a new instrument to gain and spread knowledge (Headrick, 2010). In modernity, both the 'imagination' of a national collective and the power structures of the territorial rule of nation-states were bolstered by the immediacy of nationally focussed channels of mass communication (Anderson, 1983; Deutsch, 1963). The expansion and the eventual climax of the global reach of colonial rule around 1900, as well as its decline and the concomitant rise of the nation-state fall into a historic period marked by the increasing salience of technologies of long-distance communication (Go, 2011, Ch. 6; Wimmer \& Feinstein, 2010; Wimmer \& Min, 2006).

The internal communicative integration of political units is a prerequisite for their being distinguishable from other units. In addition, according to Simmel's argument, we should also be able to observe an increase of external relationships among the differentiated units. Around the mid- $19^{\text {th }}$ century in particular there has been an 'explosive acceleration' of social change in Europe, coupled with an 'unprecedented projection overseas' (Bright \& Geyer, 2007, p. 69). The reasons for this are as manifold as the causes of capitalism. In addition to technologies such as the telegraph underpinning the new efforts to 'coordinate interactions within the world' (Geyer \& Bright, 1995, p. 1047), the increasing competition among the emerging nation-cumcolonial-states of Western Europe was the major driving force. The emerging differentiation of the world-political system into discrete national units that basically share the same characteristics resulted in convergences not only of institutional structures but also of expansionary interests. Eventually, of course, it led to the breakdown of the colonial system and to the emergence of a great number of newly independent nation-states after de- 
colonization. These changes in the structure and scope of the nation-state point to a profound transformation or 'update' of the Westphalian model (Maier, 2014).

The timing and the extent of that update is revealed by the structural analysis of international relations: In his analysis of alliance, trade and IGO networks between 1816 and 2001, Maoz (2010, ch. 3) shows that the density of inter-state relationships has increased, particularly with respect to the affiliation with intergovernmental organizations (IGOs). This development, which took off in the second half of the $19^{\text {th }}$ century (see Koch, this volume), was given additional momentum by the founding of the League of Nations in 1922 and of the United Nations in 1947. From the perspective of differentiation theory, the IGO affiliation network is the organizational equivalent to long-distance contacts based on heterogeneity: Nation-states form relationships based either on the most general shared feature of being a member of the international system or on specific interests such as the coordination of transport and communication policies. Through the thus established interstate network, 88 per cent of possible ties among states were already realized by the end of the $19^{\text {th }}$ century (Beckfield, 2010, p. 1040).

These examples from the realms of science and politics reveal a peculiar structural pattern: The dynamics of the long $20^{\text {th }}$ century are characterized by processes of further and increased differentiation within subsystems of society. This stands in contrast to previous phases of globalization, notably the European expansion of the $15^{\text {th }}$ and $16^{\text {th }}$ century. This expansion and the new 'plus ultra' worldview underpinning it (Jochum, 2017) were already consequences of the shift towards functional differentiation and of the concomitant globalization of economic, political and religious networks of communication. Yet it seems that this early phase of globalization is best understood in terms of the 'specific universalism' of function systems (Luhmann, 1997, p. 375) that transcends territorial boundaries and symbolic limitations and has thereby spurned efforts to eliminate any zones of ignorance and neglect, both socially and geographically ('hic sunt leones'). Empires are a case in point, insofar as they integrated economic, political and religious relationships across large distances but each of these spheres exhibited relatively low internal differentiation.

The specification of communication had long driven the expansion of its social and geographical reach, particularly in the cases of political power and economic transactions, but also of science and religion. From the mid- $19^{\text {th }}$ century onwards, the increasing structural 
differentiation within established global fields gained greater prominence and provided new momentum to the globalization of (specific) social relationships. The emerging heterogeneity of social roles associated with differentiated domains dramatically increased the value of communication technologies capable of bridging spatial distances. It was thus a period of 'pluralizing' rather than 'concentrating' globalization, i.e. a period of elaborating differences and distinctions within the subsystems of world society (cf. Osterhammel, 2016b, p. 815). This development was underpinned by a rapidly growing organizational field: Public administrations, central banks, universities and other organizations spread around the world, while genuinely global actors such as churches and intergovernmental organizations provided arenas for establishing and stabilizing relationships across distances. ${ }^{3}$

From the perspective of the theory of societal differentiation, the differentiation within globalizing subsystems of world society sets the long $20^{\text {th }}$ century apart from previous periods in which the establishment and expansion of global subsystems has played a more prominent role. Further and more comprehensive analyses of this aspect will need to address pertinent developments in other fields, e.g. the economy, law, education and the arts, in which we should be able to observe increasing international differentiation during that period of time as well.

\section{From adaptation to fusion}

In the course of the $19^{\text {th }}$ century, the immediacy of telecommunication and the increasing interconnectedness through the communication media of subsystems has raised the integration of world society to a new level - not in terms of unified and homogenous social structures or a solidary world community, but rather in terms of a fusion of horizons of meaning. That development took place first in Europe, where the reckless imposition of European power onto the colonies was supported and indeed preceded by a worldview that fostered expansion and the inclusion of new perspectives (Jochum, 2017). The paramount importance of Europe's territorial-political and cultural expansion during that time is hard to deny, and it is not a matter of Eurocentrism to acknowledge the 'centrality' and even 'superiority' of Europe during that

\footnotetext{
3 A more comprehensive analysis would therefore take into account another form of differentiation: the differentiation of 'levels' of social systems from 'micro' to 'macro'. Luhmann distinguishes between interaction, organization and society and argues that those three types of social systems become more detached in the course of societal evolution Luhmann (1975c). Considering the extensive 'webbing' (Geyer and Bright 1999: 1047) occurring during the second half of the $19^{\text {th }}$ century, it may well be that not only the idea of 'networks' but also 'the network' as a type of social system had its historical roots here (see Holzer 2011).
} 
period of history (Osterhammel, 2014, xx). Although functional differentiation was not a European invention, its worldwide diffusion was greatly accelerated by both colonial politics and increasing communicative interconnectedness.

The expansion of functionally specific communication on the one hand and the immediacy of mass communication on the other contributed to first calling into question and eventually eroding societal boundaries that had hitherto been able to sustain a plurality of forms of differentiation among societies that seemed to be clearly distinguishable. ${ }^{4}$ Depending on their degree of globalization, economic, political and other relationships grew more and more incongruent. It might still have been a reasonable belief at the beginning of the $19^{\text {th }}$ century that the distance between China and Europe was big enough to warrant indifference, such that, when George Earl of Macartney, ambassador of Georg III, visited Emperor Qianlongin in the year 1793, the latter could still afford to blithely ignore the status of the British king and to show virtually no interest in economic exchange. But soon economic transactions as well as military clashes such as the Opium Wars made it impossible to ignore the world beyond the perceived borders of Chinese society.

In many cases colonial and imperialist power thus enforced the dismantling of walls and borders and the increasing entanglement of formerly isolated cultures and societies. However, in some cases, such as Siam, it also occurred without manifest violence or continued even after direct pressure had subsided. In any case, the expansionary thrust of the 'European' world society made it impossible to understand any country or region of the world in complete isolation from the rest of it. Even where substantial efforts were made to fend off foreign influence, such as Japan's sakoku ('closed country') policy, they were already based on a new understanding of one's position in the world and often faded away towards the end of the $19^{\text {th }}$ century. As a result, a pattern of 'asymmetrical reference density' (Osterhammel, 2014, 911ff.) prevailed: Major parts of the world were either forced or persuaded to observe closely the developments of Western Europe.

The broadening of the horizons of social meaning in all parts of the world had significant consequences, in phenomenological terms, for what is (somewhat ambitiously) called 'global

\footnotetext{
4 The seeming self-sufficiency of some societies up until the 19th century obviously cannot mean communicative or material autonomy. Thus even though there are good reasons to avoid speaking of separate societies from a sociological perspective, prevailing self-descriptions in terms of social identities in a global environment still enjoyed some plausibility, particularly with respect to China.
} 
consciousness' and, in structural terms, for social evolution. Before a 'world without others' (Tomlinson, 1994) became thinkable as yet another and more demanding phenomenology of the global, some kind of 'consciousness of the world as a whole' (Robertson, 1992) materialized in the less demanding form of the awareness of others within the same social world. Whether those others are perceived as strange, or as superior or inferior, can only be established against the backdrop of a shared horizon of experience and action. Even substantial asymmetries do not deny but rather presuppose such a shared horizon. As the articulation of meaning includes differences and distinctions, a convergent horizon of meaning by no means implies a commonly shared worldview, but rather the awareness of other meaningful views of 'the' world.

As a structural correlate of the fusion of horizons of meaningful action into a singular global frame of reference, the single most important novelty in terms of societal evolution was the fact that boundaries that had hitherto separated one society from another became pluralized and therefore ceased to be meaningful as a distinction between a societal system and its environment: 'Neither archaic societies [...] nor the non-European civilizations could regard the European bourgeois society and its colonial expansion as an environment which called for adaptation; for not only did they lack the capacity to adapt and to persist but also because that environment could not be kept at a distance, could not remain an environment because one wanted to be like it' (Luhmann, 2017, p. 729). It could be added that even the desire not to be like them does not change the picture if, for instance, difference is pursued through emphasizing (and thus re-inventing) a tradition, which hitherto had been taken for granted, with reference to something else. The less plausible it becomes to understand 'society' as a clearly demarcated unity that could refer selectively to its environment, the more salient become other, intrasocietal ways of establishing identity and difference, e.g. the less territorially bound and more fluid concept of 'culture' (Luhmann, 1995b).

When societies cease to be able to insulate themselves from communication that could previously be externalized, the only possible framework that could accommodate and encompass all social structures and all specialized fields of action - each drawing their own boundaries more or less independently of the political ones - is a single global social system. Evolution then cannot operate on and among different societies providing sources of variation anymore. Instead, evolution can only be the evolution of world society (Stichweh, 2007, p. 538). If multiple societies cannot serve as the vehicles of evolutionary processes anymore, neither further expansion nor the diffusion of innovations are available as problem-solving 
mechanisms; instead answers to problems of internal integration and of adaption to the only remaining environment, the physical one, must be produced within world society itself (Luhmann, 2017, p. 446).

The disappearance of individual units of evolutionary processes seems to be problematic because impasses and failures immediately concern the only social system there is. The developments discussed in the previous sections hint at how mechanisms of social evolution in world society are reinforced, particularly in terms of the variation of structures, one of the three mechanisms of evolution besides selection and stabilization (Luhmann, 1997, ch. 3). First, due to the perceived simultaneity of events across the globe, it appears that more and more things happen at the same time. That increases the potential for evolution because the more things happen simultaneously, the less they can be planned and brought in line with prior expectations and planning (Luhmann, 1975d). Acceleration thus means more room for evolutionary variation.

Second, variation of social structures was also increased by a new tolerance, sometimes even a preference, for novelty. The topic is an old one from a European perspective - an appetite for novelty is certainly not exclusive to the long $20^{\text {th }}$ century. However, changes were quite suddenly adopted and sought after in many countries that had for a long time resisted change. In Japan and Thailand, for instance, the $19^{\text {th }}$ century brought reforms that in those countries in particular cannot be explained by the exogenous influence of imperialism. Rather, those as well as other countries rather suddenly changed course and began to follow a path which made novelty desirable - rather than dangerous and reproachable (Luhmann, 1995a). That holds not just for the arts and for science but also for politics: the idea of a democratic opposition, a success story of the last 150 years, has turned the ability and indeed the obligation to say 'no' into a political institution - with profound consequences around the world.

If societal evolution into modernity began with the discoveries of undesired truths and unexpected continents shaking up the traditional worldview, it has since institutionalized an unprecedented tolerance for novelty. With negation being the basic operation of change and evolution in society, it therefore stands to reason that evolution has since then accelerated. However, the fact that there is no more sociality outside world society also means that evolution cannot anymore select from the models of a range of different societies. Luhmann argues that the reduction of a plurality to one single society as the arena and carrier of evolution is a risky 
development (Luhmann, 1972, p. 337, 2017, p. 295). That risk cannot be mitigated by the mere fact that variations are increasingly produced. But it finds a partial solution in the fact that variation is also contained by subsystems of society. In the area of knowledge in particular, the early $19^{\text {th }}$ century marks the end of an encompassing evolution of ideas that could still be regarded as a single field and controlled by religious and moral considerations. That unitary model has since then largely been replaced by the evolution of separate knowledge domains: The trajectories of economic and political thought, of fads and fashion - in sports, in the arts, and in the mass media - are not anymore coordinated by any central value or societal institution. Instead they are subject to dynamics internal to the respective subsystems and domains of knowledge, dynamics that show more and more consistency or at least interdependence across national boundaries.

\section{Conclusion}

A sociological perspective on the recent history of world society only begins with observing which kinds of social change occurred during a particular period of time. Not change as such, but - to borrow Huntington's (1971) formulation - the 'change to change' is pertinent. In other words, the sequence and timing of events and innovations is not as relevant as the question as to what extent they crystallize into new structures that alter the chances of future events.

Based on the angles provided by communication, differentiation and evolutionary theories, some general arguments can be derived from the historical observations of social change in the long $20^{\text {th }}$ century. The empirical evidence suggests that both the mutual differentiation (Ausdifferenzierung) of function systems and their internal structuration (Binnendifferenzierung) served as engines of globalization. It is worth separating these two aspects because central aspects of functional differentiation had evolved long before the modern forms of internal structuration of subsystems were realized. Internal differentiation was facilitated, maybe even driven by processes of 'network compression' that were enabled by the technologies of transport and communication of the late $19^{\text {th }}$ century. The increased communicative connectedness provided by telecommunication and by differentiated role structures and knowledge domains also changed the parameters of societal evolution. In many respects, the early phases of the long $20^{\text {th }}$ century appear to have already foreshadowed the features and consequences of globalization that became more prominent later on. From the 
perspective of historical sociology, the novelties and the continuities of that long century are thus best addressed and explained as part of the somewhat longer history of modern world society.

Some of the most significant developments had their origins in the previous expansion of European society, particularly of political and economic spheres of influence and domination, or in technological innovations associated with industrialization. Notwithstanding the Eurocentrist bias of those developments, they ultimately resulted in a more polycentric world society in which centre/periphery-relationships are far less uniform (e.g. in science and religion), and which has institutionalized measures of (formal) equality within political units but also amongst them (e.g. within the international system of nation states). A closer inspection of the empirical evidence is still called for, especially regarding the shape and impact of those developments in different world regions and across various social arenas. The dialogue between sociological and historical research thus needs to continue - and not in a manner in which the historians simply 'carry grist to the sociologists' mills' (Osterhammel, 2016a, p. 25). Occasionally they might also throw some sand in the wheels of the theoretical machinery. But more importantly, the historians' sand may give the sociological conceptual wheels more empirical traction.

\section{References}

Albert, M. (2016). A Theory of World Politics. Cambridge: Cambridge University Press. Anderson, B. (1983). Imagined Communities. London: Verso.

Barth, F. (1978). Scale and network in urban western society. In F. Barth (Ed.), Scale and Social Organization (pp. 163-183). Oslo: Universitetsforlaget.

Bayly, C. A. (2004). The Birth of the Modern World, 1780-1914. Malden, MA: Blackwell.

Bayly, C. A. (2005). From archaic globalization to international networks, circa 1600-2000.

In J. H. Bentley, R. Bridenthal, \& A. A. Yang (Eds.), Interactions: Transregional Perspectives on World History (pp. 14-29). Honolulu: University of Hawai'i Press.

Beckfield, J. (2010). The social structure of the world Polity. American Journal of Sociology, 115(4), 1018-1068. 
Bright, C., \& Geyer, M. (2007). Globalgeschichte und die Einheit der Welt im 20. Jahrhundert. In S. Conrad, A. Eckert, \& U. Freitag (Eds.), Globalgeschichte: Theorien, Ansätze, Themen (pp. 53-80). Frankfurt/New York: Campus.

Conrad, S. (2016). Eine Kulturgeschichte globaler Transformation. In S. Conrad \& J. Osterhammel (Eds.), Geschichte der Welt: Vol. 4. 1750-1870: Wege zur modernen Welt (pp. 411-625). München: C.H. Beck.

Deutsch, K. W. (1963). The Nerves of Government: Models of Political Communication and Control. New York/London: Free Press/Collier-Macmillan.

Geyer, M., \& Bright, C. (1995). World history in a global age. The American Historical Review, 100(4), 1034-1060.

Go, J. (2011). Patterns of Empire: The British and American Empires, 1688 to the Present. Cambridge: Cambridge University Press.

Hanke, L. (1974). All Mankind is One: A Study of the Disputation between Bartolome de Las Casas and Juan Gines de Sepulveda in 1550 on the Intellectual and Religious Capacity of the American Indians.

Headrick, D. (2010). A double-edged sword: Communications and imperial control in British India. Historical Social Research / Historische Sozialforschung, 51-65.

Hobsbawm, E. J. (2004). The world unified [1975]. In F. J. Lechner \& J. Boli (Eds.), The Globalization Reader (2nd ed., pp. 58-62). Malden, MA: Blackwell.

Huntington, S. P. (1971). The change to change: modernization, development, and politics. Comparative Politics, 3(3), 283-322. Retrieved from http:/www.jstor.org/stable/421470 Innis, H. A. (1972). Empire and Communications. Toronto: University of Toronto Press. Jochum, G. (2017). »Plus Ultra« oder die Erfindung der Moderne: Zur neuzeitlichen Entgrenzung der okzidentalen Welt. Bielefeld: transcript.

Lechner, F. J., \& Boli, J. (2005). World Culture. Malden, MA: Blackwell.

Lübbe, H. (1996). Netzverdichtung. Zur Philosophie industriegesellschaftlicher Entwicklungen. Zeitschrift für philosophische Forschung, 50(1-2), 133-150.

Luckmann, T. (1970). On the boundaries of the social world. In M. Natanson (Ed.), Phenomenology and Social Reality. Essays in Memory of Alfred Schutz (pp. 73-100). The Hague: Martinus Nijhoff.

Luhmann, N. (1972). Rechtssoziologie (2 Bde.). Reinbek b. Hamburg: Rowohlt.

Luhmann, N. (1975a). Die Weltgesellschaft. In Soziologische Aufklärung, Band 2 (pp. 5171). Opladen: Westdeutscher Verlag. 
Luhmann, N. (1975b). Einführende Bemerkungen zu einer Theorie symbolisch generalisierter Kommunikationsmedien. In Soziologische Aufklärung, Band 2 (pp. 170-192). Opladen: Westdeutscher Verlag.

Luhmann, N. (1975c). Interaktion, Organisation, Gesellschaft. In Soziologische Aufklärung, Band 2 (pp. 9-20). Opladen: Westdeutscher Verlag.

Luhmann, N. (1975d). Weltzeit und Systemgeschichte. Über Beziehungen zwischen Zeithorizonten und Strukturen gesellschaftlicher Systeme. In Soziologische Aufklärung, Band 2 (pp. 128-166). Opladen: Westdeutscher Verlag.

Luhmann, N. (1979). Trust and Power. Chichester: John Wiley \& Sons.

Luhmann, N. (1981). Veränderungen im System gesellschaftlicher Kommunikation und die Massenmedien. In Soziologische Aufklärung, Band 3 (pp. 309-320). Opladen: Westdeutscher Verlag.

Luhmann, N. (1995a). Die Behandlung von Irritationen: Abweichung oder Neuheit? In Gesellschaftsstruktur und Semantik, Band 4 (pp. 55-100). Frankfurt/Main: Suhrkamp. Luhmann, N. (1995b). Kultur als historischer Begriff. In Gesellschaftsstruktur und Semantik, Band 4 (pp. 31-54). Frankfurt/Main: Suhrkamp.

Luhmann, N. (1997). Die Gesellschaft der Gesellschaft. Frankfurt/Main: Suhrkamp.

Luhmann, N. (2017). Systemtheorie der Gesellschaft. Berlin: Suhrkamp.

Maier, C. S. (2014). Leviathan 2.0. Cambridge, MA: Belknap Press of Harvard University Press.

Maoz, Z. (2010). Networks of Nations: The Evolution, Structure, and Impact of International Networks, 1816-2001. Cambridge: Cambridge University Press.

Meyer, J. W., Boli, J., Thomas, G. M., \& Ramirez, F. O. (1997). World society and the nation-state. American Journal of Sociology, 103(1), 144-181.

Müller, S. M. (2015). Beyond the means of 99 percent of the population: business interests, state intervention, and submarine telegraphy. Journal of Policy History, 27(3), 439-464.

Müller, S. M. (2016). Wiring the World: The Social and Cultural Creation of Global Telegraph Networks. New York: Columbia University Press.

Osterhammel, J. (2009). Die Verwandlung der Welt. Eine Geschichte des 19. Jahrhunderts. München: C.H. Beck.

Osterhammel, J. (2014). The Transformation of the World: A Global History of the Nineteenth Century. Princeton, NJ: Princeton University Press. 
Osterhammel, J. (2016a). Global history and historical sociology. In J. Belich, J. Darwin, M. Frenz, \& C. Wickham (Eds.), The Prospect of Global History (pp. 23-43). Oxford: Oxford University Press.

Osterhammel, J. (2016b). Hierarchien und Verknüpfungen. Aspekte einer globalen Sozialgeschichte. In S. Conrad \& J. Osterhammel (Eds.), Geschichte der Welt: Vol. 4. 1750-1870: Wege zur modernen Welt (pp. 627-836). München: C.H. Beck.

Osterhammel, J. (2017). Globalisierungen. In Die Flughöhe der Adler: Historische Essays zur globalen Gegenwart (pp. 12-41). München: C.H. Beck.

Pascal, B. (1910). Thoughts, Letters, and Minor Works. (Translate by W.F. Trotter, M.L. Booth, O.W. Wight). New York: P.F. Collier \& Son.

Rantanen, T. (2009). When News Was New. Malden, MA: Wiley-Blackwell.

Robertson, R. (1992). Globalization. Social Theory and Global Culture. London: Sage.

Simmel, G. (1958 [1908]). Soziologie. Untersuchungen über die Formen der Vergesellschaftung (4th ed.). Leipzig: Duncker \& Humblot.

Standage, T. (1998). The Victorian Internet: The Remarkable Story of the Telegraph and the Nineteenth Century's On-Line Pioneers. New York: Walker \& Company.

Stichweh, R. (2000). Globalisierung der Wissenschaft und die Region Europa. In Die Weltgesellschaft. Soziologische Analysen (pp. 103-129). Frankfurt/Main: Suhrkamp.

Stichweh, R. (2001). Scientific disciplines, history of. In N. J. Smelser \& P. B. Baltes (Eds.), International Encyclopedia of the Social \& Behavioral Sciences (pp. 13727-13731). Amsterdam/New York: Elsevier.

Stichweh, R. (2002). Politik und Weltgesellschaft. In K.-U. Hellmann \& R. Schmalz-Bruns (Eds.), Theorie der Politik. Niklas Luhmanns politische Soziologie (pp. 287-296). Frankfurt/Main: Suhrkamp.

Stichweh, R. (2003). Genese des globalen Wissenschaftssystems. Soziale Systeme, 9, 3-26.

Stichweh, R. (2007). Evolutionary theory and the theory of world society. Soziale Systeme, 13(1-2), 528-542. https://doi.org/10.1515/sosys-2007-1-245

Todorov, T. (1985). Die Eroberung Amerikas: Das Problem des Anderen. Frankfurt am Main: Suhrkamp.

Tomlinson, J. (1994). A phenomenology of globalization? Giddens on global modernity. European Journal of Communication, 9(2), 149-172. https://doi.org/10.1177/0267323194009002003

Tworek, H. (2014). Magic connections: German news agencies and global news networks, 1905-1945. Enterprise \& Society, 15(4), 672-686. 
Wenzlhuemer, R. (2010). Editorial - Telecommunication and globalization in the nineteenth century. Historical Social Research, 35, 7-18.

Wenzlhuemer, R. (2013). Connecting the Nineteenth-Century World: The Telegraph and Globalization. Cambridge: Cambridge University Press.

Werron, T. (2016). Gleichzeitigkeit unter Abwesenden. Zu Globalisierungseffekten elektrischer Telekommunikationstechnologien. In B. Heintz \& H. Tyrell (Eds.), Sonderheft der Zeitschrift für Soziologie. Interaktion-Organisation-Gesellschaft revisited: Anwendungen, Erweiterungen, Alternativen (pp. 251-270). Stuttgart: Lucius \& Lucius.

Werron, T. (2018). Der globale Nationalismus. Berlin: Nicolai Publishing \& Intelligence.

Wimmer, A., \& Feinstein, Y. (2010). The rise of the nation-state across the world, 1816 to 2001. American Sociological Review, 75(5), 764-790.

Wimmer, A., \& Min, B. (2006). From empire to nation-state: explaining wars in the modern world, 1816-2001. American Sociological Review, 71(6), 867-897. https://doi.org/10.1177/000312240607100601

Winseck, D. R., \& Pike, R. M. (2007). Communication and Empire: Media, Markets, and Globalization, 1860-1930. Durham, NC: Duke University Press.

Wobring, M. (2005). Die Globalisierung der Telekommunikation im 19. Jahrhundert. Pläne, Projekte und Kapazitätsausbauten zwischen Wirtschaft und Politik. Frankfurt/Main: Peter Lang.

Zerubavel, E. (1982). The standardization of time: a sociohistorical perspective. American Journal of Sociology, 88, 1-23. 